\title{
Use of HuH6 and other human-derived hepatoma lines for the detection of genotoxins: a new hope for laboratory animals?
}

\author{
Monika Waldherr ${ }^{1} \cdot$ Miroslav Mišík $^{1} \cdot$ Franziska Ferk $^{1} \cdot$ Jana Tomc $^{2,3} \cdot$ Bojana Žegura $^{2} \cdot$ Metka Filipič $^{2}$. \\ Wolfgang Mikulits ${ }^{1} \cdot$ Sören Mai ${ }^{4}$. Oskar Haas ${ }^{4}$. Wolfgang W. Huber ${ }^{1} \cdot$ Elisabeth Haslinger $^{1} \cdot$ Siegfried Knasmüller $^{1}$
}

Received: 3 July 2017 / Accepted: 26 October 2017 / Published online: 7 December 2017

(c) The Author(s) 2017. This article is an open access publication

\begin{abstract}
Cell lines which are currently used in genotoxicity tests lack enzymes which activate/detoxify mutagens. Therefore, rodentderived liver preparations are used which reflect their metabolism in humans only partly; as a consequence misleading results are often obtained. Previous findings suggest that certain liver cell lines express phase I/II enzymes and detect promutagens without activation; however, their use is hampered by different shortcomings. The aim of this study was the identification of a suitable cell line. The sensitivity of twelve hepatic cell lines was investigated in single cell gel electrophoresis assays. Furthermore, characteristics of these lines were studied which are relevant for their use in genotoxicity assays (mitotic activity, p53 status, chromosome number, and stability). Three lines (HuH6, HCC1.2, and HepG2) detected representatives of five classes of promutagens, namely, IQ and PhIP (HAAs), B(a)P (PAH), NDMA (nitrosamine), and AFB $_{1}$ (aflatoxin), and were sensitive towards reactive oxygen species (ROS). In contrast, the commercially available line HepaRG, postulated to be a surrogate for hepatocytes and an ideal tool for mutagenicity tests, did not detect IQ and was relatively insensitive towards ROS. All other lines failed to detect two or more compounds. HCC1.2 cells have a high and unstable chromosome number and mutated p53, these features distract from its use in routine screening. HepG2 was frequently employed in earlier studies, but pronounced inter-laboratory variations were observed. HuH6 was never used in genotoxicity experiments and is highly promising, it has a stable karyotype and we demonstrated that the results of genotoxicity experiments are reproducible.
\end{abstract}

Keywords Hepatic cell lines $\cdot$ p53 $\cdot$ Comet assay $\cdot$ Genotoxicity

Electronic supplementary material The online version of this article (https://doi.org/10.1007/s00204-017-2109-4) contains supplementary material, which is available to authorized users.

Siegfried Knasmüller

siegfried.knasmueller@meduniwien.ac.at

1 Department of Internal Medicine I, Institute of Cancer Research, Medical University Vienna, Borschkegasse 8a, 1090 Vienna, Austria

2 Department for Genetic Toxicology and Cancer Biology, National Institute of Biology, Večna pot 111, Ljubljana, Slovenia

3 Jozef Stefan International Postgraduate School, Jamova cesta 39, 1000 Ljubljana, Slovenia

4 Labdia Labordiagnostik GmbH, Zimmermannplatz 8, 1090 Vienna, Austria

\section{Introduction}

One of the fundamental problems of in vitro tests is the inadequate representation of drug metabolizing enzymes in cell lines which are currently used in routine screening of chemicals. Therefore, exogenous liver-derived enzyme homogenates are prepared from rodents which have been treated with enzyme inducers (Kirkland 1990). The homogenates contain phase I enzymes that convert chemicals to genotoxic metabolites and are added in experiments with bacteria and mammalian cells to mimic the biotransformation of chemicals in humans (Brandon et al. 2003). These experimental models do not reflect the situation in vivo, for example, the detoxification of electrophilic DNA reactive intermediates by phase II enzymes. As a consequence, often false results are obtained and animal experiments with rodents are performed which could be avoided with more reliable in vitro models (Kirkland et al. 2007). To develop more reliable in vitro tests, attempts were made to improve 
the sensitivity and specificity of existing tests (Fowler et al. 2012) and to establish new systems. The latter approaches include the development of 3D models, the immortalisation of primary human liver cells, the insertion of genes encoding for drug metabolizing enzymes in currently used cells, and attempts to find lines which have retained the activities of drug metabolizing enzymes (for reviews see Brandon et al. 2003; Donato et al. 2013; Zeilinger et al. 2016). Attempts to use primary hepatocytes and 3D cultures were only partly successful as they are costly and time consuming while lines expressing individual drug metabolizing enzymes are useful for mechanistic studies but not for routine testing.

In the early 1990s, Darroudi and Natarajan (1991) showed that the human-derived hepatoma line HepG2 detects representatives of many groups of genotoxic procarcinogens without addition of exogenous rodent-derived enzyme homogenate. Their findings were confirmed in subsequent experiments and it was shown that this line is able to identify DNA reactive carcinogens which give false negative results in conventional in vitro tests. Furthermore, it was found that these cells can discriminate between structurally related mutagens and non-mutagens (for review see Knasmuller et al. 1998). The cells possess a variety of drug metabolizing phase I and II enzymes in inducible form, which play a role in the activation and detoxification of chemical mutagens. Therefore, HepG2 cells were also considered as a suitable tool for the detection of synergistic and antagonistic effects in complex mixtures (Mersch-Sundermann et al. 2004). However, comparison of results obtained with $\mathrm{HepG} 2$ cells in different labs showed that the sensitivity of this line varies strongly (Knasmuller et al. 2004). One of the reasons for the poor reproducibility of experiments with these cells may be strong variations of the transcription of drug metabolizing enzymes (Wilkening et al. 2003). In the following years, a few other human hepatoma cell lines were identified which express xenobiotic drug metabolizing enzymes and can be used to detect promutagens. These lines include Hep3B (Majer et al. 2004), HCC1.2 (Winter et al. 2008) and HepaRG (Le Hegarat et al. 2014). Recently, it was postulated that the latter line is more suitable for mutagenicity and biotransformation studies than HepG2 cells (Le Hegarat et al. 2014); however, the majority of experimental data comes from one laboratory and further confirmation of this assumption is required.

The use of the different human-derived liver cells in mutagenicity tests was not based on targeted comparative screening of currently available cell lines and we hypothesized that other lines which are currently available may be equally or even more suitable for the detection of mutagens. Therefore, we performed a comprehensive study in which we compared the sensitivity of a panel of cell lines towards representatives of different classes of genotoxic carcinogens which require enzymatic activation in genotoxicity experiments.
In addition to HepG2, Hep3B, HCC1.2 and HepaRG, eight lines were included which have never been used in genotoxicty assays before. The test compounds which were used are listed in Table 1; all of them are of human relevance and require metabolic activation by different phase I and phase II enzymes. Hydrogen peroxide $\left(\mathrm{H}_{2} \mathrm{O}_{2}\right)$ was included in all experimental series as a positive control, this compound is directly active and causes damage of the DNA via formation of reactive oxygen species (ROS).

The DNA damaging properties of the different compounds were monitored in single cell gel electrophoresis (SCGE) assays which are based on the determination of DNA damage in an electric field and are increasingly used in genetic toxicology (Azqueta and Collins 2013; Collins 2015).

Additionally, we studied characteristics of the different cell lines which are relevant in regard to their potential use in genotoxicity tests, namely, (1) the morphology of the cells which provides information about their origin and similarity to primary liver cells, (2) their karyotype allowing to draw conclusions concerning their chromosomal stability, (3) measurements of the mitotic activities providing information about the duration of the repair phase which is needed for the design of tests which require cell division (e.g., gene mutation and micronucleus tests) and (4) the $p 53$ status of the cells as it was found that it plays an important role in regard to the reliability of results obtained with mammalian cell lines in mutagenicity experiments (Kirkland et al. 2007; Pfuhler et al. 2011).

\section{Materials and methods}

\section{Chemicals}

Citric acid (CAS-No. 77-92-9) and di-natriumhydrogenphosphate-dihydrate (CAS-No. 10028-24-7) for McIlvaine buffer were obtained from Merck (Darmstadt, Germany). Quinacrine dihydrochloride (CAS-No. 69-05-6) and Thymol (CAS-No. 89-83-8) for quinacrine staining solution, aflatoxin $\mathrm{B}_{1}\left(\mathrm{AFB}_{1}\right.$, CAS-No. 1162-65-8), benzo(a) pyrene (B(a)P, CAS-No. 50-32-8), hydrogen peroxide $\left(\mathrm{H}_{2} \mathrm{O}_{2}\right.$, CAS-No. 7722-84-1) and $N$-nitrosodimethylamine (NDMA, CAS-No. 62-75-9) were purchased from SigmaAldrich (St Louis, Missouri, USA). 2-amino-3-methyl3H-imidazo[4,5-f]quinolone (IQ, CAS-No. 76180-96-6) came from Toronto Research Chemicals (Toronto, Ontario, Canada) and 2-amino-1-methyl-6-phenylimidazo[4,5-b] pyridine (PhIP, CAS-No. 105650-23-5) from Santa Cruz Biotechnology, Inc. (Dallas, Texas, USA). Anti-GADPH antibody (ab9485), anti-mutant-p53 antibody (ab32049) and anti-p53 antibody (ab1101) were purchased from Abcam plc (Cambridge, UK). Anti-rabbit IgG HRP 


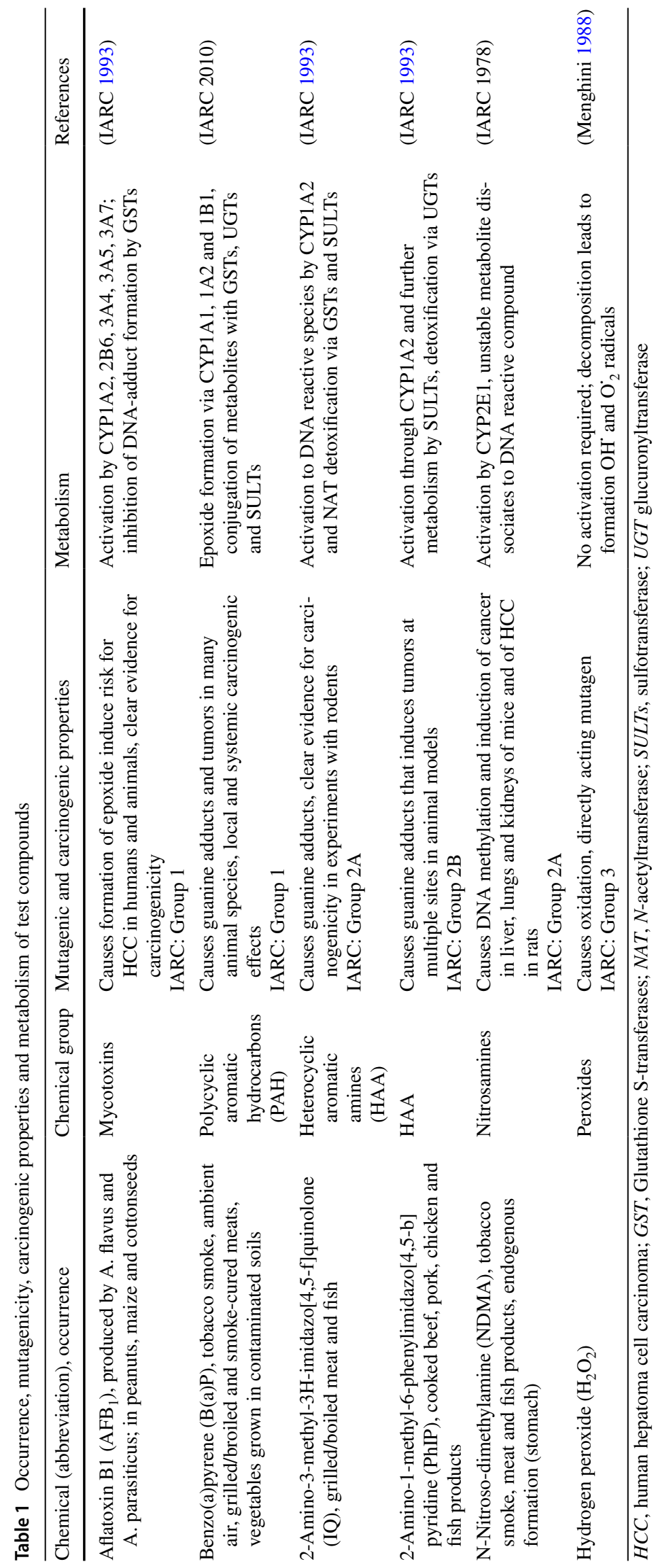


conjugate (W4018), anti-mouse IgG HRP (W4028) conjugate came from Promega Corporation (Madison, WI, USA).

Low melting point agarose (LMPA) and normal melting point agarose (NMPA) were acquired from Gibco (Paisley, UK). Inorganic salts, dimethyl sulfoxide (DMSO), propidium iodide, hydrogen peroxide, Triton X-100, Trizma base, fetal bovine serum (FBS), Dulbecco's Phosphate Buffered Saline (DPBS), Dulbecco's modified Eagle Medium (DMEM), Eagle's Minimum Essential Medium (EMEM), Minimal essential Medium Eagle (MEME), Roswell Park Memorial Institute Medium (RPMI-1640) were purchased from Sigma-Aldrich (Steinheim, Germany). William's E medium came from Thermo Fisher
Scientific (Vienna, Austria). Trypsin-EDTA was ordered from Life Technologies (Karlsruhe, Germany).

\section{Cell lines}

The origin of the cell lines is listed in Table 2 which provides also information on the cultivation conditions.

All lines were cultivated at $37^{\circ} \mathrm{C}, 96.0 \%$ humidity in 5.0 or $8.0 \% \mathrm{CO}_{2}$. All lines except HepaRG ${ }^{\mathrm{TM}}$ were grown in TC-treated flasks and dishes (Sigma-Aldrich, St Louis, Missouri, USA) as described in previous publications (for details see Table 2) and were routinely checked for mycoplasma contaminations by PCR (Mycoplasma Plus PCR Primer Set, Cat. No. 302008, Agilent Technologies, Santa Clara, CA, USA). HepaRG ${ }^{\mathrm{TM}}$ cells were cultivated and used according

Table 2 Origin and cultivation of the cell lines

\begin{tabular}{|c|c|c|c|c|}
\hline Cell line & Provider & Origin of line & Cultivation $^{\mathrm{a}}$ & Reference \\
\hline HCC 1.2 & $\begin{array}{l}\text { M. Eisenbauer (Institute of Can- } \\
\text { cer Research, MUW, Vienna, } \\
\text { Austria) }\end{array}$ & $\begin{array}{l}\text { Hepatocellular carcinoma of } \\
\text { a 56-year-old male from the } \\
\text { General Hospital of Vienna }\end{array}$ & RPMI-1640, $2.0 \mathrm{~g} / \mathrm{L} \mathrm{NaHCO}_{3}$ & (Sagmeister et al. 2008) \\
\hline Hep3B & ATCC (Manassas, VA, USA) & $\begin{array}{l}\text { Hepatocellular carcinoma of a } \\
\text { 8-year-old black male from the } \\
\text { United States }\end{array}$ & EMEM, $2.2 \mathrm{~g} / \mathrm{L} \mathrm{NaHCO}{ }_{3}$ & (Aden et al. 1979) \\
\hline HepaRG ${ }^{\mathrm{TM}}$ & $\begin{array}{l}\text { Thermo Fisher Scientific } \\
\text { (Waltham, Massachusetts, } \\
\text { USA) }\end{array}$ & $\begin{array}{l}\text { Liver tumor of a female patient } \\
\text { suffering from hepatitis } \mathrm{C} \text { in } \\
\text { France }\end{array}$ & William's E medium & (Aninat et al. 2006) \\
\hline HepG2 & ATCC (Manassas, VA, USA) & $\begin{array}{l}\text { Hepatocellular carcinoma of a } \\
\text { 15-year-old Caucasian male } \\
\text { from Argentina }\end{array}$ & $\begin{array}{l}\text { MEME, } 2.2 \mathrm{~g} / \mathrm{L} \mathrm{NaHCO}_{3}, 1 \% \\
\text { NEAA, } 1 \mathrm{mM} \mathrm{CH}{ }_{3} \mathrm{COCOONa}^{2}\end{array}$ & (Aden et al. 1979) \\
\hline HuH6 & $\begin{array}{l}\text { Isabel Fabregat (IDIBELL, Bar- } \\
\text { celona, Spain) }\end{array}$ & $\begin{array}{l}\text { Hepatoblastoma of a one-year- } \\
\text { old Japanese boy }\end{array}$ & RPMI-1640, $2.0 \mathrm{~g} / \mathrm{L} \mathrm{NaHCO}$ & (Doi 1976) \\
\hline $\mathrm{HuH7}$ & $\begin{array}{l}\text { Isabel Fabregat (IDIBELL, Bar- } \\
\text { celona, Spain) }\end{array}$ & $\begin{array}{l}\text { Well-differentiated hepatocellu- } \\
\text { lar carcinoma of a } 75 \text {-year-old } \\
\text { Japanese male }\end{array}$ & DMEM, $3.7 \mathrm{~g} / \mathrm{L} \mathrm{NaHCO}_{3}$ & (Clayton et al. 2005) \\
\hline JHH6 & $\begin{array}{l}\text { Gabriele Grassi (Department } \\
\text { of Life Sciences, University } \\
\text { Hospital of Cattinara, Trieste, } \\
\text { Italy) }\end{array}$ & $\begin{array}{l}\text { Hepatocellular carcinoma of a } \\
57 \text {-year-old Japanese female }\end{array}$ & $\begin{array}{l}\text { William's E medium, } 1 \% \text { glu- } \\
\text { tamine }\end{array}$ & (Grassi et al. 2007) \\
\hline PLC/PRF & ATCC (Manassas, VA, USA) & $\begin{array}{l}\text { Primary liver carcinoma of a } \\
24 \text {-year-old Shangaan male }\end{array}$ & MEME, $2.2 \mathrm{~g} / \mathrm{L} \mathrm{NaHCO}{ }_{3}$ & (Macnab et al. 1976) \\
\hline SK-Hep1 & ATCC (Manassas, VA, USA) & $\begin{array}{l}\text { Adenocarcinoma of a 52-year- } \\
\text { old Caucasian male }\end{array}$ & EMEM, $2.2 \mathrm{~g} / \mathrm{L} \mathrm{NaHCO}_{3}$ & (Heffelfinger et al. 1992) \\
\hline SNU-398 & $\begin{array}{l}\text { Isabel Fabregat (IDIBELL, Bar- } \\
\text { celona, Spain) }\end{array}$ & $\begin{array}{l}\text { Hhepatocellular carcinoma of a } \\
\text { Korean ( } 42 \text { years, male) patient }\end{array}$ & RPMI-1640, $2.0 \mathrm{~g} / \mathrm{L} \mathrm{NaHCO}{ }_{3}$ & (Park et al. 1995) \\
\hline SNU-449 & $\begin{array}{l}\text { Isabel Fabregat (IDIBELL, Bar- } \\
\text { celona, Spain) }\end{array}$ & $\begin{array}{l}\text { Hepatocellular carcinoma of a } \\
\text { Korean ( } 52 \text { years, male) patient }\end{array}$ & RPMI-1640, $2.0 \mathrm{~g} / \mathrm{L} \mathrm{NaHCO}{ }_{3}$ & (Park et al. 1995) \\
\hline WRL68 & $\begin{array}{l}\text { Isabel Fabregat (IDIBELL, Bar- } \\
\text { celona, Spain) }\end{array}$ & $\begin{array}{l}\text { Spontaneous transformation from } \\
\text { human embryonic liver tissue }\end{array}$ & DMEM, $3.7 \mathrm{~g} / \mathrm{L} \mathrm{NaHCO}{ }_{3}$ & (Gutierrezruiz et al. 1994) \\
\hline
\end{tabular}

ATCC American Type Culture Collection, DMEM Dulbecco's Modified Eagle Medium, EMEM Eagle's Minimum Essential Medium, IDIBELL Instituto de Investigación Biomédica de Bellvitge, MEME Minimal Essential Medium Eagle, $M U W$ Medizinische Universität Wien, NEAA NonEssential Amoni Acids, RPMI Roswell Park Memorial Institute Medium

${ }^{a} \mathrm{HuH} 6$ cells were grown in 4.0\% FBS, all other lines were grown in 10.0\% FBS, and HCC 1.2 and JHH6 were cultivated in heat-inactivated FBS (10.0\%). All lines were cultivated in 5.0\% $\mathrm{CO}_{2}$, except $\mathrm{HuH} 7$ and WRL68 (both $8.0 \% \mathrm{CO}_{2}$ ). HepaRG ${ }^{\mathrm{TM}}$ cells were cultivated as described by the provider (reconstitution with 1.0\% glutamine, for thawing: $5 \times$ HepaRG $^{\mathrm{TM}}$ Thaw, Plate and General Purpose Medium Supplement, for passaging and toxicological experiments: $5 \times$ HepaRG ${ }^{\mathrm{TM}}$ ToxMed Supplement) 
to the instructions of the manufacturer (Thermo Fisher Scientific, Vienna, Austria).

Flasks and dishes for experiments with HepaRG ${ }^{\mathrm{TM}}$ were coated with Collagen R. Collagen R stock solution (Serva Electrophoresis $\mathrm{GmbH}$, Heidelberg, Germany) was diluted to obtain a final concentration of $0.2 \mathrm{mg} / \mathrm{ml}$ collagen. Subsequently, the growth areas of the flasks or dishes were covered with $0.1 \mathrm{ml} / \mathrm{cm}^{2}$ of this solution for 30-40 min, subsequently collagen $\mathrm{R}$ solution was removed, then the flasks or dishes were air dried.

The identity of the cell lines (except of HepaRG ${ }^{\mathrm{TM}}$ ) was verified by short tandem repeat (STR) analyses (van Zij1 et al. 2011).

From all lines, except HepaRG ${ }^{\mathrm{TM}}$, cryopreserved cultures were made; cells from confluent T75 flasks were harvested and resuspended after centrifugation $\left(200 \mathrm{~g}, 5 \mathrm{~min}, 21^{\circ} \mathrm{C}\right)$ in $5.0 \mathrm{ml}$ medium. DMSO was added drop-wise (final concentration 5.0\%), then the suspensions were distributed equally to cryovials (Carl Roth, Karlsruhe, Germany), which were placed in a polystyrene box at $-80{ }^{\circ} \mathrm{C}$ for $24 \mathrm{~h}$ (to ensure slow freezing) and transferred to liquid nitrogen.

\section{Proliferation kinetics}

The proliferation kinetics and size of the cells were monitored by use of a CASY ${ }^{\circledR}$ Cell Counter and Analyzer System (TTC-2EA-1087, Schärfe System GmbH, Reutlingen, Germany) which was used as described by the manufacturer (Schärfe-System GmbH, Reutlingen, Germany). Cell lines were grown in Petri dishes $(\varnothing 6 \mathrm{~cm}$, Sigma-Aldrich, St Lois, Missouri, USA) in $5.0 \mathrm{ml}$ medium; ca. $5 \times 10^{5}$ cells were seeded in each dish at the start of the experiments. After $24 \mathrm{~h}$ intervals, the cells were detached with trypsin-EDTA (Szabo-Scandic, Vienna, Austria) and $50 \mu \mathrm{l}$ of these suspensions were transferred to CASY-cups (OLS OMNI Life Science GmbH \& Co. KG, Bremen, Germany). For each experimental point, three plates were evaluated. On the basis of the results, means and standard deviations (SDs) were calculated. Nonlinear fits with exponential growth equations (least square fits) were calculated to determine the doubling times (http://www.graphpad.com/guides/prism/5/user-guide/ prism5help.html?reg_exponential_growth.htm).

\section{Karyotyping}

Cell lines were cultured and prepared according to standard cytogenetic techniques; at least 20 metaphases per cell line were karyotyped. Slides, which had been stained with quinacrine solution (Sigma-Aldrich, St Louis, Missouri, USA), were incubated in McIlvaine solution (Merck, Darmstadt, Germany), covered with a cover slip and analyzed using Applied Spectral Imaging Case Data Manager (Version 5.5.2.2, Applied Spectral Imaging, Carlsbad, CA, USA).

\section{Determination of the $p 53$ status}

The expression of the $p 53$ gene in the different cell lines was analyzed using real-time quantitative PCR (RT-qPCR) according to the description of Straser et al. (2013). The protein was quantified by Western blotting as described by Pezdirc et al. (2013). Furthermore, the induction of p53 protein and of mRNA were investigated in all experiments after incubation of the cell lines with $30 \mu \mathrm{M}$ B(a)P.

\section{SCGE assays}

The SCGE experiments were conducted as described in an international guideline (Tice et al. 2000). Reagents for the assays (lysis solution and alkaline electrophoresis buffer) and agarose-coated slides were prepared according to Collins and Dusinska (2009).

Briefly, cells were sub-cultured in $1.0 \mathrm{ml}$ medium in 24-well tissue-culture plates (Sarstedt Inc., Newton, NC, USA). After $24 \mathrm{~h}$, the media were changed and the cells exposed to different concentrations of the test compounds or to the solvent controls (PBS or DMSO). $\mathrm{H}_{2} \mathrm{O}_{2}$ and NDMA were dissolved in PBS (pH 7.0), all other compounds in DMSO. The final DMSO concentrations in the media did not exceed $1.0 \%$. The exposure time in experiments with $\mathrm{AFB}_{1}, \mathrm{~B}(\mathrm{a}) \mathrm{P}$ and NDMA was $24 \mathrm{~h}$ and in assays with PhIP and IQ $48 \mathrm{~h}$. To terminate the treatment, the cells were washed twice with PBS $(1.0 \mathrm{ml})$, trypsinized (100 $\mu \mathrm{l}$ T/E per well, $4 \mathrm{~min})$ and then resuspended in $400 \mu \mathrm{l}$ culture medium containing FBS. Subsequently, the suspensions were transferred to Eppendorf tubes and centrifuged $(200 \mathrm{~g}, 5 \mathrm{~min})$. Cell pellets were resuspended in cold PBS. $\mathrm{H}_{2} \mathrm{O}_{2}$ treatment was conducted with cells embedded on the slides by exposure to different concentrations $(10-50 \mu \mathrm{M})$ of cold $\mathrm{H}_{2} \mathrm{O}_{2}$ solution in PBS for $5 \mathrm{~min}$, followed by washing with cold PBS (5 min).

In all experiments, acute toxic effects were determined with a CASY ${ }^{\circledR}$ Cell Counter and Analyzer System (SchärfeSystem GmbH, Reutlingen, Germany) (Lindl et al. 2005). SCGE assays were only performed when the viability of the cultures was $\geq 70 \%$ (Koppen et al. 2017). Per experimental point, two cultures were set up in parallel and from each one slide with two separate gels $(30,000$ cells/gel) was prepared. After unwinding (40 min, $\mathrm{pH}>13$ ) and electrophoresis ( $30 \mathrm{~min}, 0.75 \mathrm{~V} / \mathrm{cm}, \sim 300 \mathrm{~mA}, 4{ }^{\circ} \mathrm{C}, \mathrm{pH}>13$ ), 50 cells were evaluated per gel (200 cells per experimental point). As an endpoint, we determined the tail intensities (" $\%$ DNA in tail") with a computer-aided system Comet Assay IV (Perceptive Instruments, Bury St Edmunds, UK), which is at present the most widely used parameter (Collins et al. 2008; Moller 2006). For each gel, the median of the tail intensity was calculated. 


\section{Statistical analyses}

The results of the genotoxicity screening experiments were analyzed using GraphPad Prism 5 to perform ordinary oneway ANOVA followed by Dunnett's multiple comparisons. The results of the RT-qPCR analyses were evaluated with the $\Delta \Delta \mathrm{Ct}$ method; GAPDH was used as a reference gene. $P$ values $\leq 0.05$ were considered as statistically significant.

\section{Results}

\section{General characteristics of the liver cell lines}

Figure S1 shows morphology of the different cell types, their morphological characteristics are described in Table 3, which contains also information concerning their size, which was in a relatively narrow range (i.e., between 16 and $22 \mu \mathrm{m}$ ). In agreement with literature data (see Table 2), we found that most lines have an epithelial morphology, however, some cell types (SNU-398, SNU-449, SK-Hep1 and WRL68) had mesenchymal features and most of them (except SK-Hep1) had a polygonal form.

The features of HuH6 cells differ from those of the other cell types, i.e., they are relatively undifferentiated and we found in agreement with previous studies that they contain numerous glycogen granules, which are only rarely seen in other liver-derived cells (Figure S1E) (Doi 1976).

The proliferation kinetics of the different cells are shown graphically in Figures S2a and b. On the basis of the experimental data, the doubling times were calculated (Table 3 ). The "fastest" lines were HuH7 and WRL68 (23-27 h and

Table 3 Characterization of the morphology, growth kinetics, karyotype and p53-status of the different cell lines

\begin{tabular}{|c|c|c|c|c|c|c|c|c|}
\hline \multirow[t]{2}{*}{ Cell line } & \multirow[t]{2}{*}{ Morphology } & \multirow[t]{2}{*}{ Doubling time $(\mathrm{h})$} & \multirow{2}{*}{$\begin{array}{l}\text { Chromo- } \\
\text { some } \\
\text { number }^{\mathrm{a}}\end{array}$} & \multicolumn{2}{|c|}{$\begin{array}{l}\text { P53 protein expression } \\
\text { (Western Blot) }^{\mathrm{b}}\end{array}$} & \multicolumn{2}{|c|}{$\begin{array}{l}\text { P53 gene expression (RT- } \\
\text { qPCR) }^{\mathrm{c}}\end{array}$} & \multirow[t]{2}{*}{ Size $(\mu \mathrm{m})$} \\
\hline & & & & Background & Induced $^{\mathrm{d}}$ & Background & Induced $^{\mathrm{e}}$ & \\
\hline HCC 1.2 & Epithelial & $46-53$ & $111-127$ & + & + & 1 & $1.50 \pm 0.33$ & $\varnothing 22$ \\
\hline Hep3B & Epithelial liver parenchymal & $41-53$ & $62-67$ & - & - & 0 & 0 & $\varnothing 19$ \\
\hline HepaRG $^{\mathrm{TM}}$ & Epithelial granular hepatocyte-like & $48-69$ & $46-47$ & + & + & 1 & $0.87 \pm 0.14$ & $\varnothing 20$ \\
\hline HepG2 & $\begin{array}{l}\text { Epithelial resemble liver paren- } \\
\text { chym }\end{array}$ & $41-57$ & $49-53$ & + & +++ & 1 & $1.48 \pm 0.18$ & $\varnothing 18$ \\
\hline HuH6 & $\begin{array}{l}\text { Epithelial desmosomes and glyco- } \\
\text { gen granules in the cytoplasm }\end{array}$ & $45-50$ & $82-86$ & + & ++ & 1 & $1.26 \pm 0.01$ & $\varnothing 23$ \\
\hline $\mathrm{HuH7}$ & $\begin{array}{l}\text { Epithelial, grow in multilayered } \\
\text { islands, often piled up, periph- } \\
\text { eral cells surrounding the island } \\
\text { appeared to be flattened }\end{array}$ & $23-27$ & $65-111$ & + & + & 1 & $1.13 \pm 0.01$ & $\varnothing 22$ \\
\hline JHH6 & $\begin{array}{l}\text { Epithelial undifferentiated mor- } \\
\text { phology }\end{array}$ & $33-47$ & $53-70$ & + & + & 1 & $1.00 \pm 0.03$ & Ø 19 \\
\hline PLC/PRF & $\begin{array}{l}\text { Epithelial polygonal in shape } \\
\text { with well-defined borders, many } \\
\text { binucleated cells }\end{array}$ & $36-43$ & $39-58$ & + & + & 1 & $0.89 \pm 0.05$ & $\varnothing 20$ \\
\hline SK-Hep1 & $\begin{array}{l}\text { Mesenchymal, HCC-like cell } \\
\text { shape }\end{array}$ & $35-54$ & $59-61$ & + & + & 1 & $1.04 \pm 0.12$ & $\varnothing 19$ \\
\hline SNU-398 & $\begin{array}{l}\text { Mesenchymal round-spindle, } \\
\text { multinuclear, trabecular arrange- } \\
\text { ments, anaplastic small cells }\end{array}$ & $30-33$ & $59-64$ & + & + & 1 & $1.03 \pm 0.15$ & $\varnothing 16$ \\
\hline SNU-449 & $\begin{array}{l}\text { Mesenchymal polygonal, single } \\
\text { or double nuclear cells, compact } \\
\text { growth pattern, trabecular }\end{array}$ & $28-33$ & $52-55$ & + & + & 1 & $0.95 \pm 0.03$ & $\varnothing 21$ \\
\hline WRL68 & $\begin{array}{l}\text { Mesenchymal polygonal to spindle } \\
\text { shape, some cells rounded, } \\
\text { morphology similar to human } \\
\text { hepatocytes }\end{array}$ & $25-30$ & $61-254$ & + & + & 1 & $0.96 \pm 0.03$ & $\varnothing 20$ \\
\hline
\end{tabular}

\footnotetext{
${ }^{\mathrm{a}}$ Analysis of 50 quinacrine-stained metaphase spreads

${ }^{\mathrm{b}}$ In HCC 1.2 and SNU-398 mutated p53 was detected with an anti-mutant-p53 antibody

${ }^{\mathrm{c}}$ TaqMan ${ }^{\circledR}$ Gene Expression Assay, TP53 Hs00153349_m1, AB (Coverage: 7 transcripts for p53), for Hep3B, HepaRG ${ }^{\mathrm{TM}}$, JHH6 and SNU-449 TaqMan ${ }^{\circledR}$ Gene Expression Assay, TP53 Hs01034249_m1, AB (Coverage: 15 transcripts for p53) was used

${ }^{\mathrm{d}}$ Induction of p53-protein expression was monitored after treatment with $30 \mu \mathrm{M} \mathrm{B}(\mathrm{a}) \mathrm{P}$ for $24 \mathrm{~h}$. No expression is indicated with -, background expression with + , induced expression with ++ and highly induced expression with +++

${ }^{\mathrm{e}}$ Statistically significant induction of gene expression after treatment with $30 \mu \mathrm{M} \mathrm{B}(\mathrm{a}) \mathrm{P}$ for $24 \mathrm{~h}$ is indicated with asterisks
} 
25-30 h, respectively), relatively slow mitotic activities were found with HepaRG and HuH6 cells (48-69 h and 45-50 h).

The results of the karyotyping experiments are summarized in column four of Table 3 . It can be seen that the chromosome numbers and also the range varied substantially. High numbers (i.e. more than 100 chromosomes per cell) were detected in $\mathrm{HCC} 1.2, \mathrm{HuH} 7$ and WRL68. The numbers in HepaRG and HepG2 are similar to those found in primary human hepatocytes. Figure S3 shows a representative karyogram of HuH6 cells. The typical number of chromosomes in this cell line was between 82 and 86 . In some lines, the number of chromosomes was in a narrow range (SK-Hep1, Hep3B, HepaRG, and HuH6) while a broader range was found in other cell types (e.g., in WRL68).

Western Blot and RT-qPCR analyses (Table 3; Figure S4) revealed that Hep3B cells lack p53 expression at the transcriptional and at the protein level while HCC1.2 and SNU398 possess mutated $\mathrm{p} 53$ protein. The protein was induced in HepG2 and HuH6 after B(a)P treatment for $24 \mathrm{~h}$.

\section{Sensitivity of the different hepatic cell lines towards model mutagens}

The results which were obtained in representative SCGE experiments with the different liver lines are summarized in Table 4. It can be seen that the responses varied strongly. Five lines (PLC/PRF, SK-Hep1, SNU-398, SNU-449, and WRL68) were not responsive to the different model compounds. In $\mathrm{HuH} 7$, induction of DNA damage was found with high doses of $\mathrm{B}(\mathrm{a}) \mathrm{P}$ and NDMA but not with the other genotoxins. Hep3B cells were in general insensitive but a moderate effect was obtained with B(a)P. HepaRG cells detected four out of five genotoxins (all compounds except IQ). In HCC1.2, HepG2, and HuH6 cells, all compounds induced positive results. It is also notable that the latter line and HCC1.2 cells were the most sensitive ones, i.e., positive results were observed with most mutagens at relatively low concentrations.

$\mathrm{H}_{2} \mathrm{O}_{2}$ was used in all experiments as a positive control. We observed strong differences of the sensitivity of the different cell lines towards this peroxide. The results which were obtained in subsequent dose response experiments with selected cell lines are summarized in Fig. 1. Interestingly, HepaRG cells were by far less sensitive as HepG2, HuH6, and HCC1.2.

\section{Reproducibility of HuH6 experiments}

The reproducibility of results obtained with HuH6, HepG2, and $\mathrm{HCC} 1.2$ cells with different diagnostic mutagens in two independent experiments is depicted in Fig. 2. The reproducibility of results obtained with $\mathrm{HuH} 6, \mathrm{HepG} 2$, and
HCC1.2 cells with the different model mutagens in two independent experiments is depicted in Fig. 2.

Induction factors (IF) represent the ratios of \%DNA in tail induced in chemically treated cells and respective untreated controls. It can be seen that the values obtained in two independent experiments with different mutagens are in general similar in experiments with $\mathrm{HuH6}$ and for certain model compounds (AFB1, $\mathrm{H}_{2} \mathrm{O}_{2}$ and IQ) also in assays with HCC1.2 while relatively strong differences of the responses were observed with HepG2. Experiments with HepaRG were not included as the reproducibility of comet experiments was addressed already in a study by Le Hegarat et al. (2014).

\section{Discussion}

The results of the SCGE experiments confirm our assumption that several human-derived hepatoma cell lines detect the genotoxic properties of different groups of DNA reactive carcinogens without addition of exogenous enzyme activation mix. Seven out of twelve lines were sensitive towards $\mathrm{AFB}_{1}$, six detected B(a)P, five NDMA, four PhIP, and three IQ. Three hepatic lines (HepG2, HuH6, and HCC1.2) were sensitive towards representatives of all groups, HepRG to four compounds, $\mathrm{HuH7}$ to two; only four lines were not responsive at all.

The sensitivity of the different hepatic lines was in general similar. The most pronounced effects were observed in general with $\mathrm{AFB}_{1}$ and $\mathrm{B}(\mathrm{a}) \mathrm{P}$, which were positive at concentrations between 5 and $10 \mu \mathrm{M}$ while higher doses of IQ and NDMA (in most cases $\geq 100 \mathrm{mM}$ ) were required to cause significant effects. It is notable that HCC1.2 was clearly more sensitive towards these latter compounds as the other lines.

The most important finding of the present study is the identification of a hepatic line (HuH6) which is apparently more suitable for the detection of genotoxins as the other liver-derived lines. This line was isolated more than 40 years ago from a hepatic tumor of a 1-year-old boy (Doi 1976). HuH6 cells have never been used in genotoxicity studies before according to our knowledge, however, some articles have been published concerning the impact of drugs on programmed cell death and cell signaling (Canal et al. 2015; Soini et al. 2017); furthermore, some data are available which concern the expression of drug metabolizing enzymes (i.e., CYP3A4, CYP3A7, CYP4F2, CYP4F3 and CYP2B6, and UGT1A1) in this line (Goldstein et al. 2013; Hosomi et al. 2011; Sugatani et al. 2010). In the present investigation, we obtained positive results with all test compounds; as shown in Fig. 2, these results were highly reproducible. The line has an intact and inducible $p 53$ and an epithelial morphology, its chromosome number is in a narrow range 


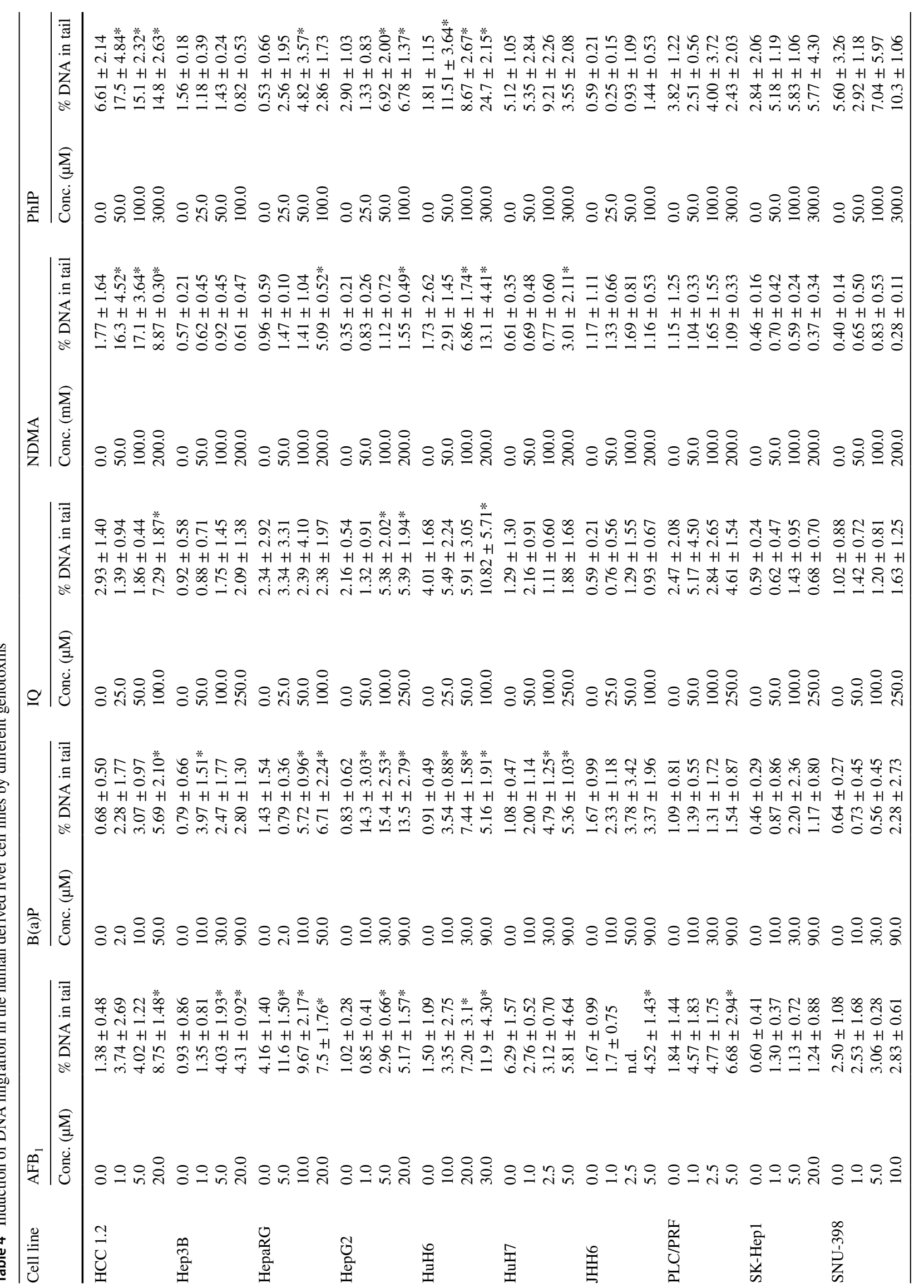




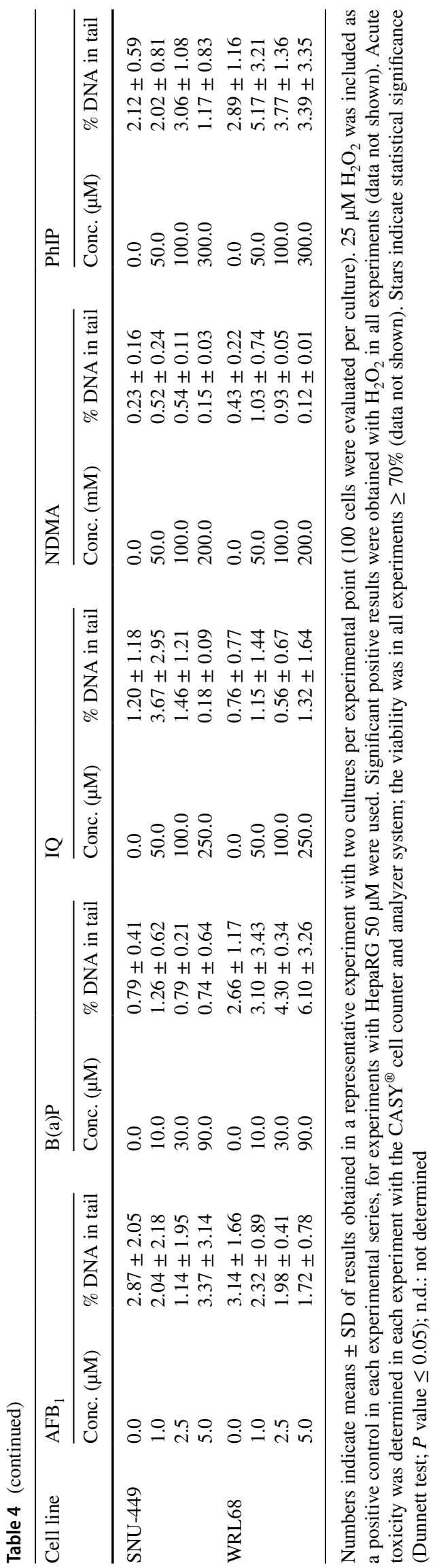

and twice as high as in primary hepatocytes; the doubling time is similar to that of most other lines.

Also HepG2 and HCC1.2 detected all five diagnostic genotoxins in the present experiments. The sensitivity of HepG2 can be explained by representation of a broad variety of drug metabolizing enzymes (Donato et al. 2013; Mersch-Sundermann et al. 2004); with HCC1.2, no results of enzyme measurements have been published, but gene expression analyses indicate that various phase I and II enzymes are present in this line (Winter et al. 2008). Our findings with HCC1.2 are in agreement with earlier findings (Winter et al. 2008). However, we found in the present study that these cells have an abnormal and unstable karyotype (i.e., 111-127 chromosomes) and a mutated $p 53$. These findings indicate that they are not suitable for routine testing of chemicals; as mentioned above, it was stressed by Fowler et al. (2012) that p53 competent cell lines are less prone to give false results as cells with mutated $p 53$.

With HepG2 cells, clear positive results were obtained with all reference compounds in the present study. These results are in agreement with earlier reports (Knasmuller et al. 2004; Winter et al. 2008). However, the main problem of the use of this line is the poor reproducibility which is evident when results of experiments from different groups are compared in which similar or identical experimental concentrations were used (Knasmuller et al. 2004). Comparison of the LOEC values which were obtained in different laboratories show strong variations. For example, the concentration of $\mathrm{AFB}_{1}$ which was required to induce significant DNA migration was in previous experiments under identical conditions 20 -fold lower as in the present study (Winter et al. 2008). Also the levels of $\mathrm{B}(\mathrm{a}) \mathrm{P}$ which caused positive results varied strongly in different labs (Uhl et al. 2000; Valentin-Severin et al. 2003). Another reason for this phenomenon may be strong fluctuations of the expression of genes encoding for drug metabolizing enzymes (Wilkening et al. 2003). Figure 2 concerns the reproducibility of comet experiments with different cell lines. It is evident that the results which were obtained with HepG2 vary over a relatively broad range, while results with HuH6 were in both experimental series similar. The reproducibility of experiments with HepaRG are described in a paper of Le Hegarat et al. (2014), the extent of comet formation which was observed in several independent experiments with cyclophosphamide was similar. Further information concerning the reproducibility of assays with $\mathrm{HCC} 1.2$ cells can be found in the publication of Winter et al. (2008). It is interesting that we found in the present study similar effects in independent experiments with hydrogen peroxide but fluctuations were observed with promutagens (which require metabolic activation). This indicates that the differences are probably due to instability of activities of drug metabolizing enzymes. 

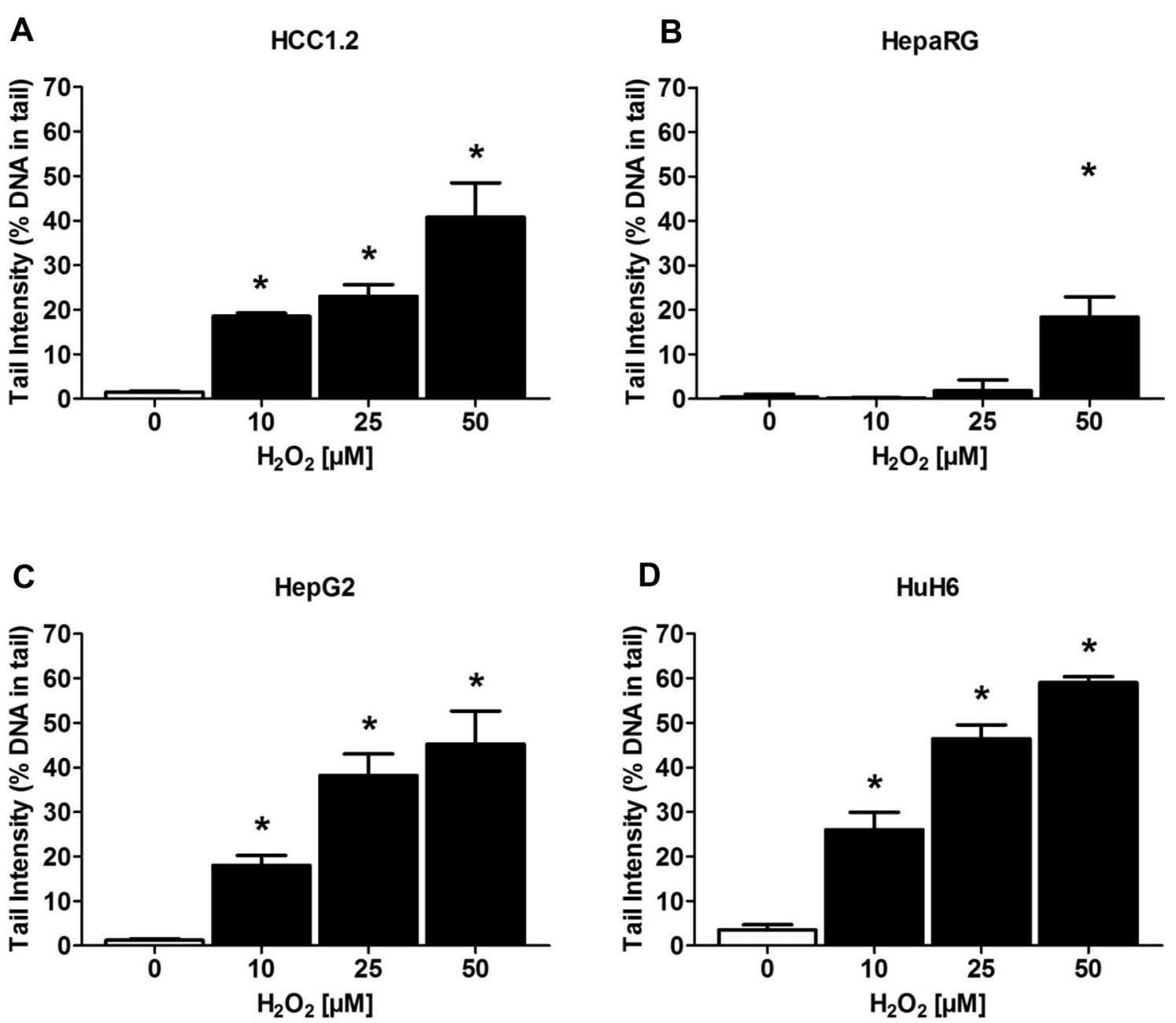

Fig. 1 Induction of DNA damage in different human-derived liver cell lines by $\mathrm{H}_{2} \mathrm{O}_{2}$. Bars indicate mean \pm SD of medians of four measurements (per experimental point in total 200 cells), asterisks indicate statistical significance (Dunnett's Multiple Comparison Test, $P \leq 0.05$ )

Recently, it was suggested that HepaRG cells, which are only commercially available, have a unique potential to detect genotoxins (Josse et al. 2012; Le Hegarat et al. 2014) and it was also stressed that these cells represent a reliable surrogate to human hepatocytes as they express high levels of phase I and II enzymes (Aninat et al. 2006; Antherieu et al. 2010). In the present study, HepaRG cells detected only four of five promutagens ( $\mathrm{AFB}_{1}, \mathrm{~B}(\mathrm{a}) \mathrm{P}, \mathrm{PhIP}$, and NDMA) and their sensitivity was in most cases identical or lower as that of the other cell types (HCC1.2, HepG2 or HuH6). With the heterocyclic aromatic amine IQ, negative results were obtained under all experimental conditions. These observations are in agreement with previous findings of Lehegerad et al. (2010) in SCGE and micronucleus experiments. They may be due to lack of metabolic activation of this heterocyclic aromatic amine which is catalyzed by CYP1A and $\mathrm{N}$-acetyl transferase (NAT) (IARC 1993; Turesky et al. 1998). The latter enzyme is also essential for the activation of aromatic amines (Chevereau et al. 2017) which are an important group of genotoxic carcinogens (Vineis and Pirastu 1997). In this context, it is notable that negative results were obtained in SCGE experiments with HepaRG cells with two representatives of this group (2-acetylaminofluorene and 2,4-diaminotoluene) (Le Hegarat et al. 2014); data for di-nitro-PAHs (another relevant group of environmental mutagens) which require activation by NAT (Rothman et al. 1996; Talaska et al. 1996) are not available according to our knowledge. The cells have not been characterized in regard to their NAT activities, and results of gene expression analyses (RT-qPCR) showed that the expression of genes encoding for NAT1/NAT2 is not affected by HAAs (Dumont et al. 2010). Another disadvantage of HepaRG cells is their insensitivity towards induction of DNA damage by reactive oxygen species. As shown in Fig. 1, these cells were by far less responsive towards $\mathrm{H}_{2} \mathrm{O}_{2}$-induced DNA damage as the other lines (HepG2, HuH6, and HCC1.2). It is well documented that ROS play a crucial role in the induction of DNA damage by a large number of chemicals including 

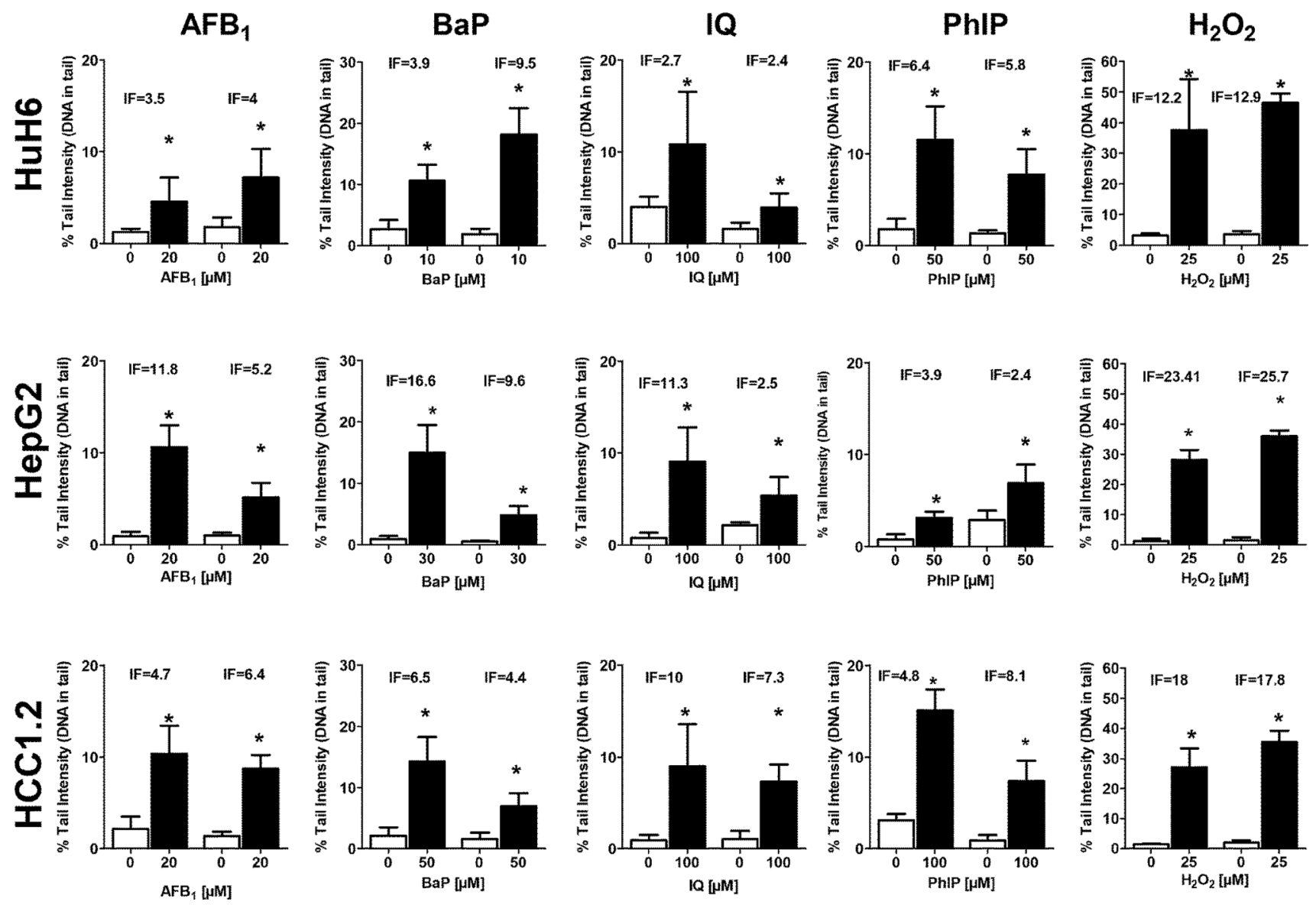

Fig. 2 Reproducibility of SCGE experiments with different model mutagens in hepatoma cell lines. The cells were treated with different concentrations of the model compounds either for $24 \mathrm{~h}\left(\mathrm{AFB}_{1}\right.$, $\mathrm{B}(\mathrm{a}) \mathrm{P}$ ) or for $48 \mathrm{~h}$ (IQ and $\mathrm{PhIP}$ ), and $\mathrm{H}_{2} \mathrm{O}_{2}$. IF values represent the ratio of chemically induced comet formation (\% DNA in tail) vs. DNA migration in corresponding controls. Bars show the results of two separate experiments; for each experimental point, at least two different cultures were set up in parallel, one slide with two gels was made per culture and 100 cells were counted per slide. Bars indicate mean \pm SD of medians of four measurements; asterisks indicate statistical significance (Student $T$ Test, $p \leq 0.05$ )

observed in the primary cells. The increased sensitivity of the hepatocytes is probably due to higher activities of drug metabolizing enzymes (in particular of cytochrome P450 isozymes which are involved in the activation of promutagens). Westerink and Schoonen (2007a, b) analyzed comparatively the levels of the phase I and phase II enzymes in human hepatocytes and HepG2, and found substantially higher activities in the primary cells.

Taken together, the results of the present study show that several human-derived liver cell lines detect promutagens without addition of rodent-derived liver homogenate. Furthermore, they indicate that HuH6 is the most promising line which may be useful for routine testing of chemicals. Results of experiments with HepaRG cells indicate that differentiated cells express higher levels of drug metabolizing enzymes (Aninat et al. 2006; Kanebratt and Andersson 2008); therefore protocols for genotoxicity assays with such cells were developed (Josse et al. 2012; Le Hegarat et al. nitrosamine and the HAA substantially stronger effects were 
2010, for reasons of comparison, we also used differentiated HepaRG in the present experiments). Another possibility to improve the sensitivity and possibly also the reproducibility of experiments is the development of three dimensional models. It was recently suggested that $3 \mathrm{D}$ growth of HepG2 cells in spheroids is more suitable for cytotoxicity screening of chemicals (Ramaiahgari et al. 2014). Furthermore, preliminary findings of SCGE experiments with these cells indicate that growth in spheroids makes the cells more sensitive towards $\mathrm{B}(\mathrm{a}) \mathrm{P}$ as a consequence of increased levels of CYP1A1 (Shah et al. 2015). The possibility to increase the sensitivity and reproducibility of experiments with Huh6 by optimization of the cultivation conditions and of the exposure time is currently explored. Further experimental work with compounds that give false positive results in conventional in vitro tests as well as the characterization of drug metabolizing enzymes to confirm this assumption is also in progress.

Acknowledgements Open access funding provided by Austrian Science Fund (FWF). This study was supported by the Austrian Science Funds (FWF): I2059-B20 and the Slovenian Research Agency (ARRSJ1-6730) "Development of human derived liver cell lines for genotoxicity testing". The authors are grateful to the COST Action CA15132, 'hCOMET', for support. The authors are thankful to M. Eisenbauer and to $\mathrm{H}$. Huber for their advice in regard to the cultivation of the cells.

Open Access This article is distributed under the terms of the Creative Commons Attribution 4.0 International License (http://creativecommons.org/licenses/by/4.0/), which permits unrestricted use, distribution, and reproduction in any medium, provided you give appropriate credit to the original author(s) and the source, provide a link to the Creative Commons license, and indicate if changes were made.

\section{References}

Aden DP, Fogel A, Plotkin S, Damjanov I, Knowles BB (1979) Controlled synthesis of HBsAg in a differentiated human liver carcinoma-derived cell line. Nature 282(5739):615-616

Aninat C, Piton A, Glaise D et al (2006) Expression of cytochromes $\mathrm{P} 450$, conjugating enzymes and nuclear receptors in human hepatoma HepaRG cells. Drug Metab Dispos 34(1):75-83. https:// doi.org/10.1124/dmd.105.006759

Antherieu S, Chesne C, Li R et al (2010) Stable expression, activity, and inducibility of cytochromes P450 in differentiated HepaRG cells. Drug Metab Dispos 38(3):516-525. https://doi.org/10.1124/ dmd.109.030197

Azqueta A, Collins AR (2013) The essential comet assay: a comprehensive guide to measuring DNA damage and repair. Arch Toxicol 87(6):949-968. https://doi.org/10.1007/s00204-013-1070-0

Brandon EF, Raap CD, Meijerman I, Beijnen JH, Schellens JH (2003) An update on in vitro test methods in human hepatic drug biotransformation research: pros and cons. Toxicol Appl Pharmacol 189(3):233-246

Canal F, Anthony E, Lescure A et al (2015) A kinome siRNA screen identifies HGS as a potential target for liver cancers with oncogenic mutations in CTNNB1. BMC Cancer 15:1020. https://doi. org/10.1186/s12885-015-2037-8
Chevereau M, Glatt H, Zalko D, Cravedi JP, Audebert M (2017) Role of human sulfotransferase $1 \mathrm{~A} 1$ and $N$-acetyltransferase 2 in the metabolic activation of 16 heterocyclic amines and related heterocyclics to genotoxicants in recombinant V79 cells. Arch Toxicol. https://doi.org/10.1007/s00204-017-1935-8

Clayton RF, Rinaldi A, Kandyba EE et al (2005) Liver cell lines for the study of hepatocyte functions and immunological response. Liver Int 25(2):389-402. https://doi. org/10.1111/j.1478-3231.2005.01017.x

Collins AR (2015) The comet assay: a heavenly method! Mutagenesis 30(1):1-4. https://doi.org/10.1093/mutage/geu079

Collins AR, Dusinska M (2009) Applications of the comet assay in human biomonitoring. In: Dhawan A, Anderson D (eds) The comet assay in toxicology, issues in toxicology, No 5. RSC Publishing, Cambridge, UK, pp 201-226

Collins AR, Oscoz AA, Brunborg G et al (2008) The comet assay: topical issues. Mutagenesis 23(3):143-151. https://doi.org/10.1093/ mutage/gem051

Doi I (1976) Establishment of a cell line and its clonal sublines from a patient with hepatoblastoma. Gann 67(1):1-10

Donato MT, Jover R, Gomez-Lechon MJ (2013) Hepatic cell lines for drug hepatotoxicity testing: limitations and strategies to upgrade their metabolic competence by gene engineering. Curr Drug Metab 14(9):946-968

Dumont J, Josse R, Lambert C et al (2010) Differential toxicity of heterocyclic aromatic amines and their mixture in metabolically competent HepaRG cells. Toxicol Appl Pharmacol 245(2):256-263. https://doi.org/10.1016/j.taap.2010.03.008

Fowler P, Smith R, Smith K et al (2012) Reduction of misleading ("false") positive results in mammalian cell genotoxicity assays. II. Importance of accurate toxicity measurement. Mutat Res 747(1):104-117. https://doi.org/10.1016/j.mrgentox.2012.04.013

Goldstein I, Rivlin N, Shoshana OY et al (2013) Chemotherapeutic agents induce the expression and activity of their clearing enzyme CYP3A4 by activating p53. Carcinogenesis 34(1):190-198. https://doi.org/10.1093/carcin/bgs318

Grassi G, Scaggiante B, Farra R et al (2007) The expression levels of the translational factors eEF1A $1 / 2$ correlate with cell growth but not apoptosis in hepatocellular carcinoma cell lines with different differentiation grade. Biochimie 89(12):1544-1552. https://doi. org/10.1016/j.biochi.2007.07.007

Gutierrezruiz MC, Bucio L, Souza V, Gomez JJ, Campos C, Carabez A (1994) Expression of some hepatocyte-like functional-properties of Wrl-68 cells in culture. In Vitro Cell Dev An 30A(6):366-371

Heffelfinger SC, Hawkins HH, Barrish J, Taylor L, Darlington GJ (1992) SK HEP-1: a human cell line of endothelial origin. In Vitro Cell Dev Biol 28A(2):136-142

Hosomi H, Fukami T, Iwamura A, Nakajima M, Yokoi T (2011) Development of a highly sensitive cytotoxicity assay system for CYP3A4-mediated metabolic activation. Drug Metab Dispos 39(8):1388-1395. https://doi.org/10.1124/dmd.110.037077

IARC (1993) Some naturally occuring substances: food items and constituents, heterocyclic aromatic amines abd mycotoxins, 56th edn. IARC Monographs on the Evaluation of Carcinogenic Risks to Humans, Lyon

Josse R, Rogue A, Lorge E, Guillouzo A (2012) An adaptation of the human HepaRG cells to the in vitro micronucleus assay. Mutagenesis 27(3):295-304. https://doi.org/10.1093/mutage/ger076

Kanebratt KP, Andersson TB (2008) Evaluation of HepaRG cells as an in vitro model for human drug metabolism studies. Drug Metab Dispos 36(7):1444-1452. https://doi.org/10.1124/ dmd.107.020016

Kirkland JD (1990) Basic Mutagenicity Tests_-UKEMS Recomended Procedures. Cambridge University, Cambridge

Kirkland DJ, Aardema M, Banduhn N et al (2007) In vitro approaches to develop weight of evidence (WoE) and mode of action (MoA) 
discussions with positive in vitro genotoxicity results. Mutagenesis 22(3):161-175. https://doi.org/10.1093/mutage/gem006

Knasmuller S, Parzefall W, Sanyal R et al (1998) Use of metabolically competent human hepatoma cells for the detection of mutagens and antimutagens. Mutat Res 402(1-2):185-202

Knasmuller S, Mersch-Sundermann V, Kevekordes S et al (2004) Use of human-derived liver cell lines for the detection of environmental and dietary genotoxicants; current state of knowledge. Toxicology 198(1-3):315-328. https://doi.org/10.1016/j.tox.2004.02.008

Knasmuller S, Nersesyan A, Misik M et al (2008) Use of conventional and -omics based methods for health claims of dietary antioxidants: a critical overview. Br J Nutr 99(1):3-52. https://doi. org/10.1017/S0007114508965752

Koppen G, Azqueta A, Pourrut B, Brunborg G, Collins AR, Langie SAS (2017) The next three decades of the comet assay: a report of the 11th International Comet Assay Workshop. Mutagenesis 32(3):397-408. https://doi.org/10.1093/mutage/gex002

Le Hegarat L, Dumont J, Josse R et al (2010) Assessment of the genotoxic potential of indirect chemical mutagens in HepaRG cells by the comet and the cytokinesis-block micronucleus assays. Mutagenesis 25(6):555-560. https://doi.org/10.1093/mutage/ geq039

Le Hegarat L, Mourot A, Huet S et al (2014) Performance of comet and micronucleus assays in metabolic competent HepaRG cells to predict in vivo genotoxicity. Toxicol Sci 138(2):300-309. https:// doi.org/10.1093/toxsci/kfu004

Lindl T, Lewandowski B, Schreyogg S, Staudte A (2005) An evaluation of the in vitro cytotoxicities of 50 chemicals by using an electrical current exclusion method versus the neutral red uptake and MTT assays. Altern Lab Anim 33(6):591-601

Macnab GM, Alexander JJ, Lecatsas G, Bey EM, Urbanowicz JM (1976) Hepatitis-B surface-antigen produced by a human hepatoma cell line. Brit J Cancer 34(5):509-515. https://doi. org/10.1038/Bjc.1976.205

Majer BJ, Mersch-Sundermann V, Darroudi F, Laky B, de Wit K, Knasmuller S (2004) Genotoxic effects of dietary and lifestyle related carcinogens in human derived hepatoma (HepG2, Hep3B) cells. Mutat Res 551(1-2):153-166. https://doi.org/10.1016/j. mrfmmm.2004.02.022

Menghini R (1988) Genotoxicity of active oxygen species in mammalian cells. Mutat Res 195(3):215-230

Mersch-Sundermann V, Knasmuller S, Wu XJ, Darroudi F, Kassie F (2004) Use of a human-derived liver cell line for the detection of cytoprotective, antigenotoxic and cogenotoxic agents. Toxicology 198(1-3):329-340. https://doi.org/10.1016/j.tox.2004.02.009

Moller P (2006) Assessment of reference values for DNA damage detected by the comet assay in human blood cell DNA. Mutat Res 612(2):84-104. https://doi.org/10.1016/j.mrrev.2005.10.001

Monteith DK, Vanstone J (1995) Comparison of DNA damage from genotoxicants using the microgel electrophoresis assay with primary cultures of rat and human hepatocytes. Mutat Res 345(1-2):79-86

Natarajan AT, Darroudi F (1991) Use of human hepatoma cells for in vitro metabolic activation of chemical mutagens/carcinogens. Mutagenesis 6(5):399-403

Park JG, Lee JH, Kang MS et al (1995) Characterization of cell lines established from human hepatocellular carcinoma. Int J Cancer 62(3):276-282

Pezdirc M, Zegura B, Filipic M (2013) Genotoxicity and induction of DNA damage responsive genes by food-borne heterocyclic aromatic amines in human hepatoma HepG2 cells. Food Chem Toxicol 59:386-394. https://doi.org/10.1016/j.fct.2013.06.030

Pfuhler S, Fellows M, van Benthem J et al (2011) In vitro genotoxicity test approaches with better predictivity: summary of an IWGT workshop. Mutat Res 723(2):101-107. https://doi.org/10.1016/j. mrgentox.2011.03.013
Ramaiahgari SC, den Braver MW, Herpers B et al (2014) A 3D in vitro model of differentiated HepG2 cell spheroids with improved liver-like properties for repeated dose high-throughput toxicity studies. Arch Toxicol 88(5):1083-1095. https://doi.org/10.1007/ s00204-014-1215-9

Rothman N, Bhatnagar VK, Hayes RB et al (1996) The impact of interindividual variation in NAT2 activity on benzidine urinary metabolites and urothelial DNA adducts in exposed workers. Proc Natl Acad Sci USA 93(10):5084-5089

Sagmeister S, Eisenbauer M, Pirker C et al (2008) New cellular tools reveal complex epithelial-mesenchymal interactions in hepatocarcinogenesis. Brit J Cancer 99(1):151-159. https://doi.org/10.1038/ sj.bjc. 6604440

Shah UK, de Oliveira Mallia J, Singh N, BéruBé K, Doak SH, Jenkins GJS (2015) Optimization of a three-dimensional in vitro spheroid model of HepG2 cells for genotoxicity testing - abstracts of the 38th Annual Meeting of the United Kingdom Environmental Mutagen Society, 12th-15th July 2015 at Plymouth University, UK. Mutagenesis 30(6):877

Soini T, Pihlajoki M, Kyronlahti A, Andersson LC, Wilson DB, Heikinheimo M (2017) Downregulation of transcription factor GATA4 sensitizes human hepatoblastoma cells to doxorubicin-induced apoptosis. Tumour Biol 39(3):1010428317695016. https://doi. org/10.1177/1010428317695016

Straser A, Filipic M, Zegura B (2013) Cylindrospermopsin induced transcriptional responses in human hepatoma HepG2 cells. Toxicol In Vitro 27(6):1809-1819. https://doi.org/10.1016/j. tiv.2013.05.012

Sugatani J, Osabe M, Kurosawa M, Kitamura N, Ikari A, Miwa M (2010) Induction of UGT1A1 and CYP2B6 by an antimitogenic factor in HepG2 cells is mediated through suppression of cyclindependent kinase 2 activity: cell cycle-dependent expression. Drug Metab Dispos 38(1):177-186. https://doi.org/10.1124/ dmd.109.029785

Talaska G, Underwood P, Maier A, Lewtas J, Rothman N, Jaeger M (1996) Polycyclic aromatic hydrocarbons (PAHs), nitro-PAHs and related environmental compounds: biological markers of exposure and effects. Environ Health Perspect 104(Suppl 5):901-906

Tice RR, Agurell E, Anderson D et al (2000) Single cell gel/comet assay: guidelines for in vitro and in vivo genetic toxicology testing. Environ Mol Mutagen 35(3):206-221

Turesky RJ, Constable A, Richoz J et al (1998) Activation of heterocyclic aromatic amines by rat and human liver microsomes and by purified rat and human cytochrome P450 1A2. Chem Res Toxicol 11(8):925-936. https://doi.org/10.1021/tx980022n

Uhl M, Helma C, Knasmuller S (2000) Evaluation of the single cell gel electrophoresis assay with human hepatoma (Hep G2) cells. Mutat Res 468(2):213-225

Valentin-Severin I, Le Hegarat L, Lhuguenot JC, Le Bon AM, Chagnon MC (2003) Use of HepG2 cell line for direct or indirect mutagens screening: comparative investigation between comet and micronucleus assays. Mutat Res 536(1-2):79-90

van Zijl F, Mall S, Machat G et al (2011) A human model of epithelial to mesenchymal transition to monitor drug efficacy in hepatocellular carcinoma progression. Mol Cancer Ther 10(5):850-860. https://doi.org/10.1158/1535-7163.MCT-10-0917

Vineis P, Pirastu R (1997) Aromatic amines and cancer. Cancer Causes Control 8(3):346-355

Ward JF, Evans JW, Limoli CL, Calabro-Jones PM (1987) Radiation and hydrogen peroxide induced free radical damage to DNA. Br J Cancer Suppl 8:105-112

Westerink WM, Schoonen WG (2007a) Cytochrome P450 enzyme levels in HepG2 cells and cryopreserved primary human hepatocytes and their induction in HepG2 cells. Toxicol In Vitro 21(8):15811591. https://doi.org/10.1016/j.tiv.2007.05.014 
Westerink WM, Schoonen WG (2007b) Phase II enzyme levels in HepG2 cells and cryopreserved primary human hepatocytes and their induction in HepG2 cells. Toxicol In Vitro 21(8):1592-1602. https://doi.org/10.1016/j.tiv.2007.06.017

Wilkening S, Stahl F, Bader A (2003) Comparison of primary human hepatocytes and hepatoma cell line Hepg2 with regard to their biotransformation properties. Drug Metab Dispos 31(8):1035-1042. https://doi.org/10.1124/dmd.31.8.1035

Winter HK, Ehrlich VA, Grusch M et al (2008) Use of four new humanderived liver-cell lines for the detection of genotoxic compounds in the single-cell gel electrophoresis (SCGE) assay. Mutat Res 657(2):133-139. https://doi.org/10.1016/j.mrgentox.2008.08.012

Zeilinger K, Freyer N, Damm G, Seehofer D, Knospel F (2016) Cell sources for in vitro human liver cell culture models. Exp Biol Med (Maywood) 241(15):1684-1698. https://doi. org/10.1177/1535370216657448 